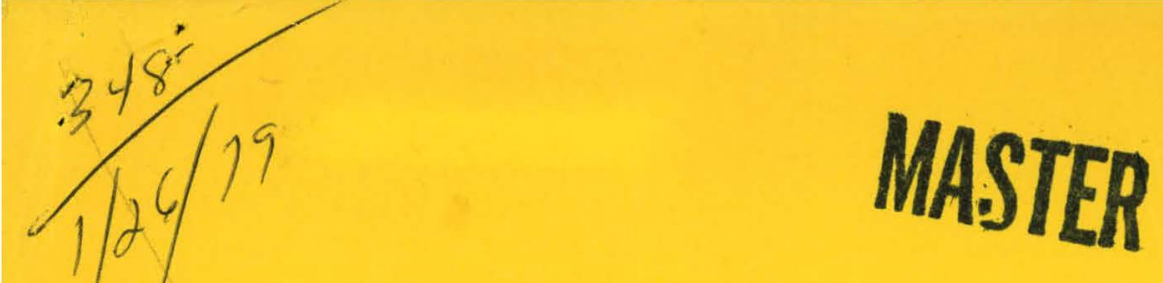

DOE/NASA CONTRACTOR REPORT h. 2148

DOE/NASA CR-150859

\title{
DESIGN AND INSTALLATION PACKAGE FOR SOLAR HOT WATER SYSTEM
}

Prepared from documents furnished by

Solar Engineering and Manufacturing Company

1091 Southwest lst Way

Deerfield Beach, FL 33441

Under Contract NAS8-32248 with

National Aeronautics and Space Administration

George C. Marshall Space Flight Center, Alabama 35812

For the U.S. Department of Energy

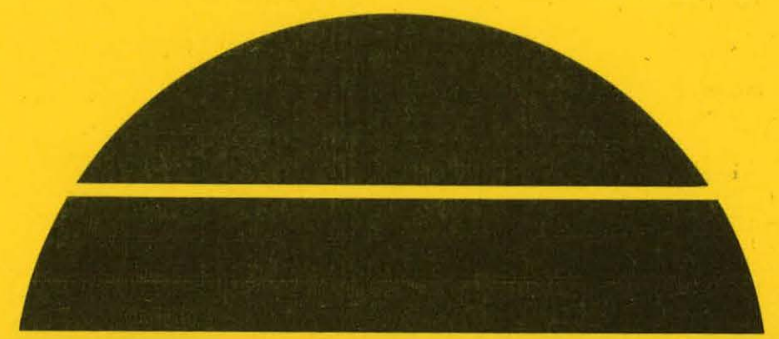

\section{U.S. Department of Energy}




\section{DISCLAIMER}

This report was prepared as an account of work sponsored by an agency of the United States Government. Neither the United States Government nor any agency Thereof, nor any of their employees, makes any warranty, express or implied, or assumes any legal liability or responsibility for the accuracy, completeness, or usefulness of any information, apparatus, product, or process disclosed, or represents that its use would not infringe privately owned rights. Reference herein to any specific commercial product, process, or service by trade name, trademark, manufacturer, or otherwise does not necessarily constitute or imply its endorsement, recommendation, or favoring by the United States Government or any agency thereof. The views and opinions of authors expressed herein do not necessarily state or reflect those of the United States Government or any agency thereof. 


\section{DISCLAIMER}

Portions of this document may be illegible in electronic image products. Images are produced from the best available original document. 
This report was prepared to document work sponsored by the United States Government. Ne1ther the United States nor 1ts agents the Unfted States Department of Energy, the United States National Aeronautics and Space Adininletration, nor any federsl employees, nor any of thefl contractors, sticcrtractors or the1r employees, make any warranty, express or 1mplite, or assume any legal 11ab1lity or responsibllity for the scculscy, completeness, or usefulness of any Information, apparatus, product or process disclosed, or represent that its use would not infringe privately owned rights. 


1. REPORT NO.
DOE/ NASA CR-150859

2. GOVERNMENT ACCESSION NO.

3. RECIPIENT'S CATALOG NO.

4. TITLE AND SUBTITLE

Design and Installation Package for Solar Hot Water System

5. REPORT DATE

December 1978

6. PERFORMING ORGANIZATION COIDE

7. AUTHOR(S)

8. PERFORMING ORGANIZATION REPORT \#

9. PERFORMING ORGANIZATION NAME AND ADDRESS

10. WORK UNIT NO.

Solar Engineering and Manufacturing Company

1091 Southwest 1st Way

Deerfield Beach, FL 33441

12. SPONSORING AGENCY NAME AND ADDRESS

National Aeronautics and Space Administration

Washington, "D. C. 20546

11. CONTRACT OR GRANT NO.

NAS8-32248

13. TYPE OF REPOR' \& PERIOD COVERED

Contractor Report

14. SPONSORING AGENCY CODE

15. SUPPLEMENTARY NOTES

This work was done under the technical management of Mr. Ralph Cole, George C. Marshall Space Flight Center, Alabama.

16. ABSTRACT

This report contains the design and installation procedure for the Solar Engineering and Manufacturing Company's solar hot water system. Included are the system performance specifications, system design drawings, hazard analysis and other information necessary to evaluate the design and install the system.

Some reformatting and renumbering of pages have been done in the interest of clarity.

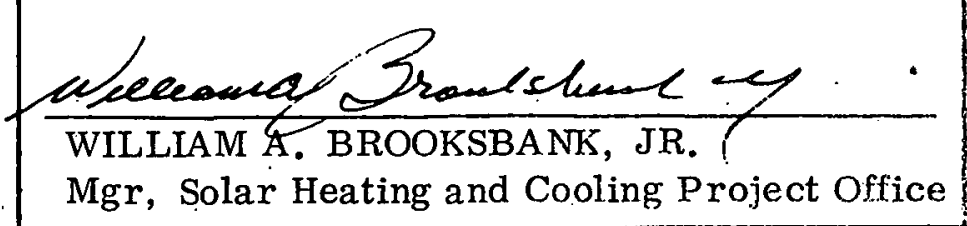

19. SECURITY CLASSIF. (of thls roport) 20. SECURITY CLASSIF. (of thi" pogo)

Unclassified

Unclassified

31

NTIS 
THIS PAGE

\section{WAS INTENTIONALLY LEFT BLANK}




\section{TABLE OF CONTENTS}

System Performance Specification 1

$\begin{array}{ll}\text { Acceptance Data Package } & 11\end{array}$

$\begin{array}{lll}\text { Hazard Analysis } & 15\end{array}$

Installation Manual $\ldots \ldots$ 
SEMCO

SYSTEM PERFORMANCE SPECIEICATIONS

SHC -3021

\subsection{Introduction}

This System Performance Specification establishes the requirements for the design and performance of the solar powered Domestic Hot water (DHW) System to be delivered by the system contractor. It designated the Interim Performance Criteria (IPC) applicable to the above system and defines any anticipated deviations. The appendices specify the performance for the Site \#l system and subsystems and site $\frac{\| 2}{\pi} 2$ system and subsystems together with installation drawings for both sites.

\subsection{Applicable Documents}

This section lists the Government and Contractor reference Documents Applicable to the System Performance Specification and the appendices attached hereto.

\subsection{Government Documents}

2.11 Interim Performance Criteria for Solar Heating and Combined Heating/Cooling Systems and dweilings, January 1, 1975 published by the U. S. Department of Housing and Urban Development (HUD) .

2.12 Solar Heating and Cooling Development Program Request for Proposal No. AP32-75-406 by the National Aeronautics and Space Administration dated October 17, 1975.

2.13 Contract document NAS8-32248 between National Aeronautics and Space Administration (NASA) and Solar Engineering \& Manufacturing Co. (SEMCO, ten pages with Appendices A through G, dated October 28, 1976.

\subsection{System Contractor Documents}

2.21 Response to Request for Proposal AP32-75-405 by the Solar Engineering \& Manufacturing CO. (SEMCO) dated March 5 , 1976 .

2.22 Collector Performance Test Report from Florida Solar Energy Center for Hodel FP 40-3 submitted in the Harch monthly report and for Model FP 40-4 ( 1 " insulation) recently submitted to FSEC for further testing. Second Performance Test. Report currently pending.

2.23 Required Documentation for Prototype Design Review submitted May 2, 1977.

2.24 Site Data Acquisition System instrumentation design submitted on April 22, 1977 and revised on May 25, 1977.

2.25 Various documents submitted with this System Perform- 
ance Specification as part of the May report as follows:

2.251 List of Materials to be Delivered

2.252 Testing of Materials to be Delivered

2.253 Testing of Installed systems

2.254 Installation, Operation and Maintenance Manual

2.255 Design Data Brochure

2.256 Training Program

3.0 Application of IPC by Type of System

The application of each paragraph of the Interim Performance Criteria (IPC) to each system is provided in the following table.

\section{TABLE I}

Residential Systems, Interim Performance Criteria Sumnary

Following 6 Pages 
RESIDENTIAL SYSTEMS, INTERIM PERFORMANCE CRITERIA SUMAMARY

SHET 1 of 6

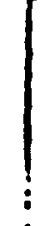

\section{AppucaTley}

a - applicable tó systemsinoicated

1 - APPLICABLE TO SYSTEM ANO BUILDNNO

MA - NOT APPLICABIE
IYPEBYIELT

H - hEATINO

HC - HEATING ANO COOLING

HW - MOT WATER

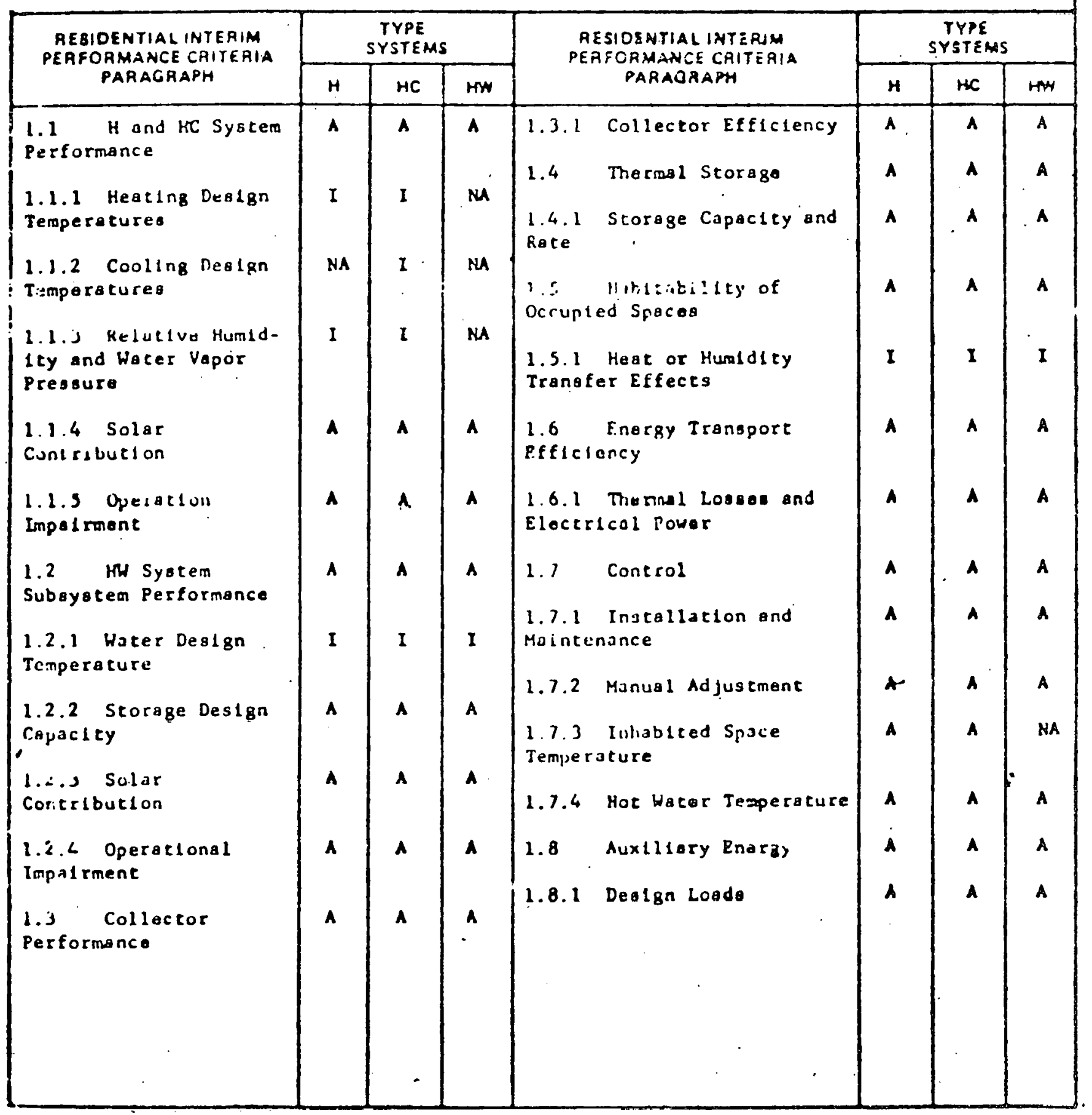


TABLE I

\section{RESIDENTIAL SYSTEMS, INTERIM PERFORMAAKE CRITERIA SUAHMARY}

SHEET 2 OF 6

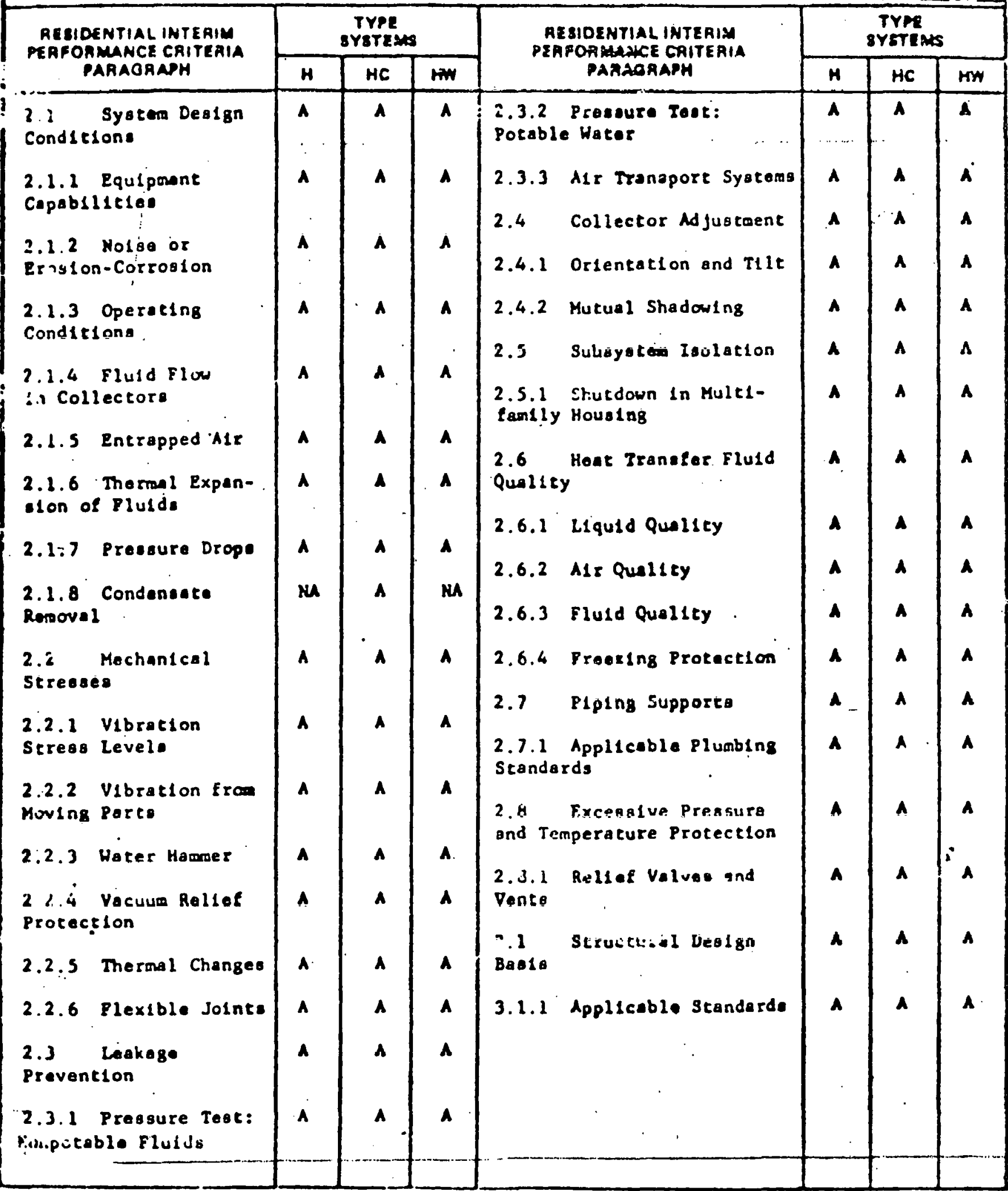


RESIDENTIAL SYSTEMS, IATERIM PERFOR HHACE CRITERIA SUMHARY

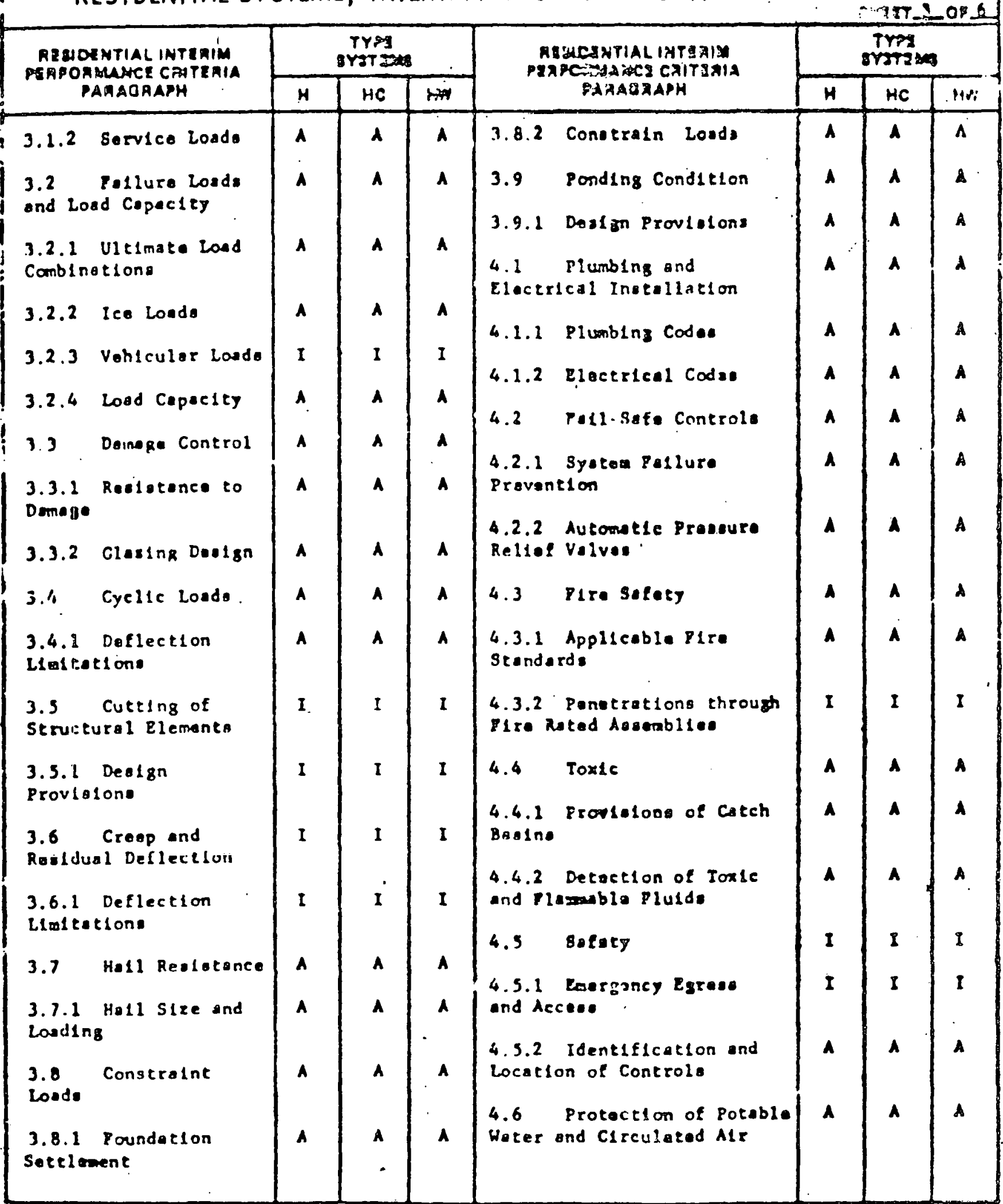


RESIDENTIAL SYSTEMS, INTERIM PERFURMANCE CRITERIA SUMHARY

HEET_LO 6

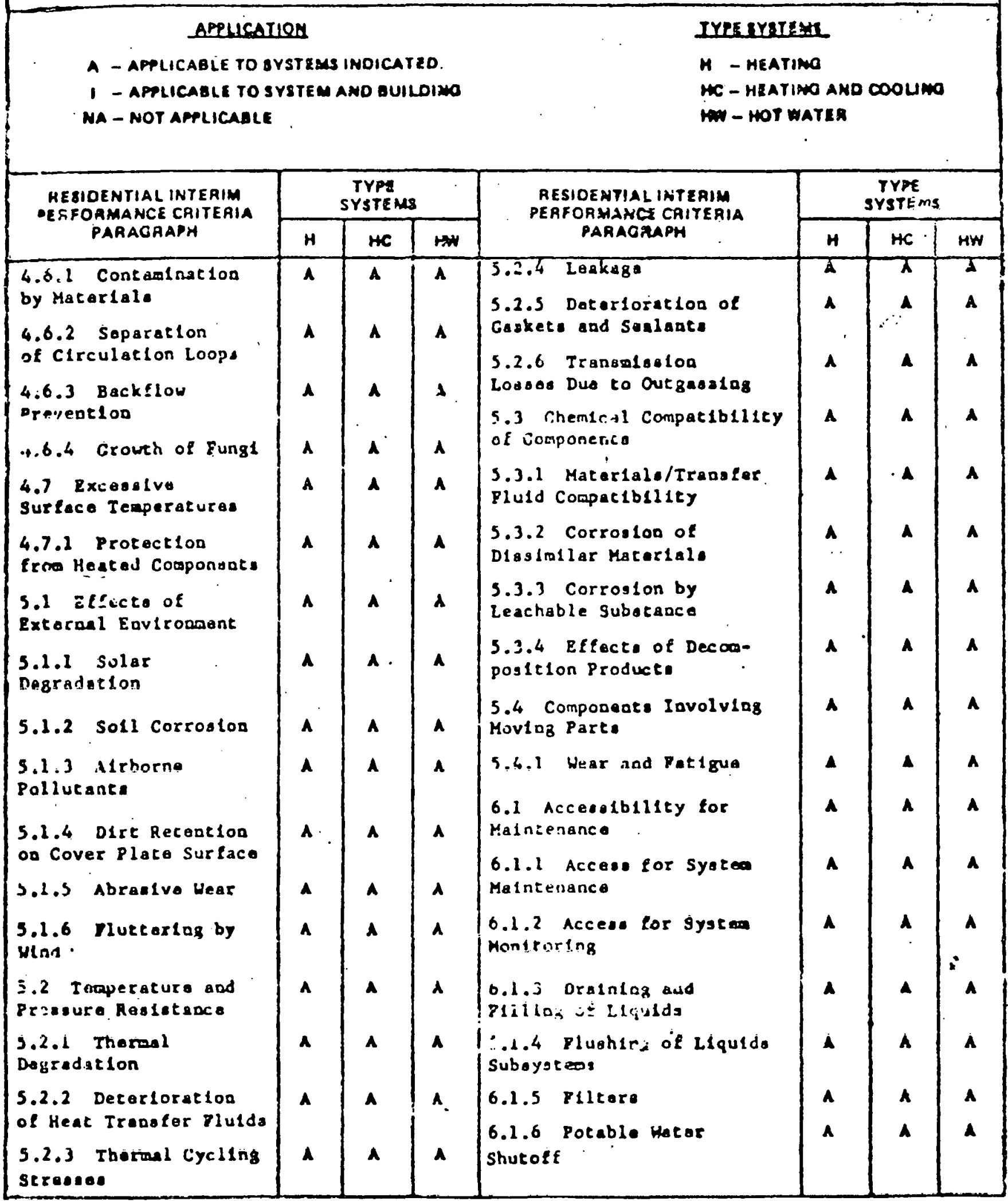


DATE

RESIDENTIAL SYSTEMS, INTERIM PERFORIMANCE CRITERIA SUMMARY

cxist 2 or 8

\section{APRucatios}

A - Applicable to systemg indicated

1 - APPLICABLE TO BYSTEM ANO DUILOHO

NA - NOT APPLICABLE
IXP10YTI3:2

H - HATINO

HC - MUATINO AWD COOLINO

MW - hOT warsa

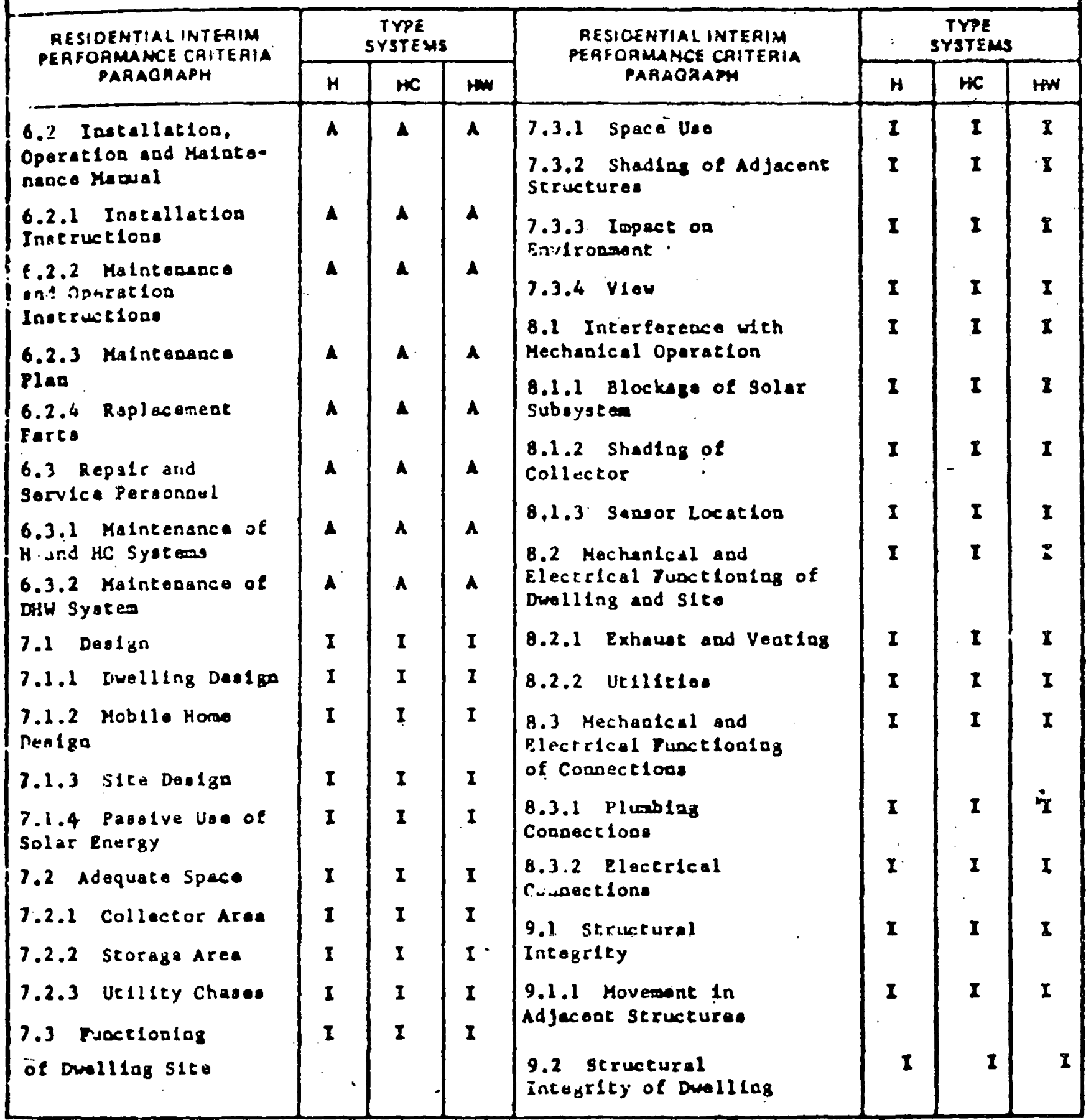


TABLE I

SPECIFiuminn NO.

CONTIMUATION BWET

\section{RESIDENTIAL SYSTEMS, INTERIM PERFCRMANCE CRITERIA SUMUHARY}

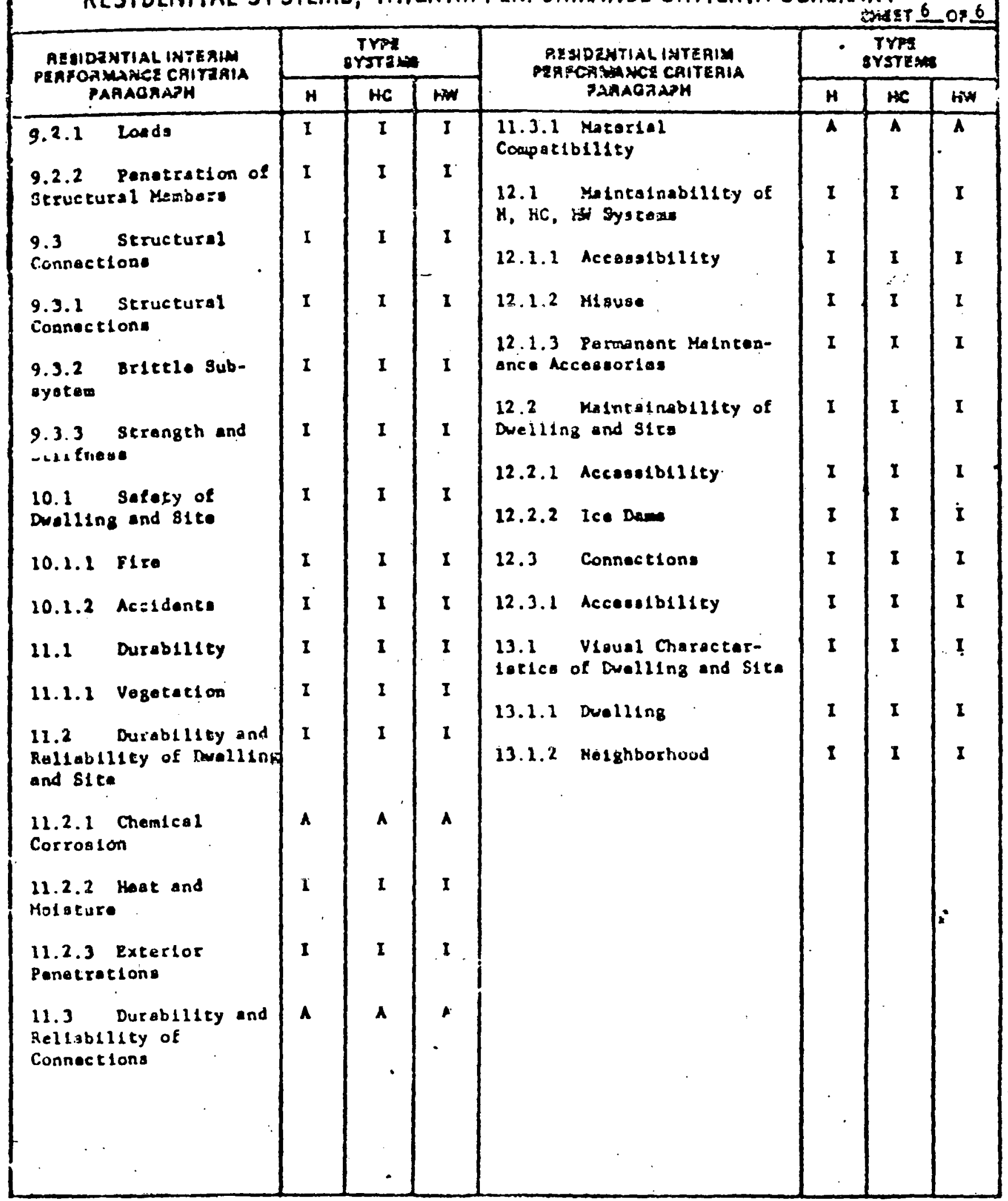


4.0 Deviation From Interim Performance Criteria

None

5.0 Government Furnished Property

5.1 Site Date Acquisition System supplied and installed by IBM.

5.2 Instrumentation equipment including thermowells, sensors, wirïng and J-Box supplied by IBM and installed by system contractors.

6.0 Government Directed Requirements

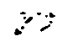

See Contract NAS8-32248

7.0 Geographical Area

7.1 Operational Test Site.\#1.' The Contract Domestic Hot water (DHW) System is for a single family residence located in the Loxahatchee Wildife Refuge, Palm Beach County, west of Boynton Beach, near Ft. Lauderdale, Florida. Operating altitude is approximately 20 feet above sea level.

7.2 Operations Test Site \#2. The Contract Domestic Hot Water (DHW) system is for a single family residence located at a Public Housing Project, 1777 Wren Ave., Macon, Georgia. Operating altitude is approximately 500 feet above sea level.

8.0 System Appendices

Appendix A Domestic Hot Water System

Operational Test Site \#1

Loxahatchee Wildlife Refugee

Single Family Residence

Model - Semco DHW 2/120 DF

Appendix B Domestic Hot Water System

Operational Test Site \#2

Macon, Georgia

Single Family Residence

Model - Semco DHW 2/120 DWHE 
Operational Site \#l - Loxahatachee Wildlife Refuge

Hot Water

75 gallons of potable hot water shall be delivered at no less than $3 \mathrm{gal} / \mathrm{min}$ at temperatures no less than $140^{\circ} \mathrm{F}$. Recovery time shall be no greater than 8 hrs. The average hot water heating load will be $1,12 \overline{5,000}$. BTU/Month of which $10 \%$ is provided by auxiliary energy.

$(75 \times 8 . \overline{33} \times(140-80) \times 30=1,125,000$ BTU $)$

Opcrating Requirements

$\because \because$

The maximum elcctrical energy required to drive the solar portion of the system at its rated capacity shall be no greater than $0.10 . \mathrm{KW} / \mathrm{hr}$. The maximum electrical energy required to dirive the complete system shall be no greater than $4.6 \mathrm{KW} / \mathrm{hr}$. The average yearly electrical energy required to drive the system shall be no greater than 688 K.W/Yr.

$(112,500 \div 3,412 \times 12=396 \mathrm{KW} / \mathrm{yr})$ plus

$(0.10 \times 8 \times 365=292 \mathrm{~kW} / \mathrm{Yr})=688 \mathrm{KW} / \mathrm{Yr}$

Physical Data

\begin{tabular}{|c|c|c|c|}
\hline Subsystem & $\begin{array}{l}\text { Design Life } \\
\text { no less than } \\
\end{array}$ & $\begin{array}{l}\text { Weight (Filled) } \\
\text { no greater than }\end{array}$ & $\begin{array}{l}\text { Installation } \\
\text { dimension }\end{array}$ \\
\hline $\begin{array}{l}\text { Storage } \\
\text { Potable later }\end{array}$ & 5 yrs & $\begin{array}{l}1,200 \text { lbs } \\
1,000 \text { lbs }\end{array}$ & $120 \mathrm{gal}$ \\
\hline $\begin{array}{l}\text { Aux - E } \\
\text { Collector }\end{array}$ & $\begin{array}{r}5 \text { yrs } \\
20 \text { yrs }\end{array}$ & $1801 \mathrm{bs}$ & $\begin{array}{l}4.5 \cdot \mathrm{K} \cdot \mathrm{W} \\
4^{\prime} \times 10^{\prime}\end{array}$ \\
\hline Controller & 5 yrs & 3 lbs & $3^{\prime \prime} \times 4^{\prime \prime} \times 6^{\prime \prime}$ \\
\hline Pump & 5 yrs & 10 lbs & $1 / 20$ H.P \\
\hline Transport & 5 Y $5 \mathrm{a}$ & $1 \mathrm{lb} / \mathrm{ft}$ & - \\
\hline
\end{tabular}


1.0 INTRODUCIIONS

The following report is a description of the test site residential solar water heating systems installed and. modified by SFMCO. The list of materials and schematics are for the "as is" configeration. No further modifications are anticipated. This data is prepared and presented in anticipation of the "Operational Test Review", scheduled for November 9, 1978 at the Macon, Georgia site.

2.0 MATERIAL LIST

2.1 COLLECTORS - Semco Flat plate - two (2) supplied Model 40-7 - Double Glazed with Tempered Glass Total area of 80 sq. ft.

2.2 STORAGE TANKS - State Ind - 120 Gallon tank Macon Site - Double wall heat exchanger using a Roll-Bond copper pannel wrapped axound the lower portion of the steel tank with graphite filled polybutaline mastic between the tank and Roll-Bond pannel. Loxahatchee Site - Standard djrect feed solar tank. Both tanks have a 4,500 watt electric booster element.

2.3 CIRCULATING PUMPS - Grundfos - Hot water Macon Site UP 26-64 F $1 / 12 \mathrm{H} . \mathrm{P}$. Loxahatchee Site UP 20-42 F $1 / 20 \mathrm{H} . \mathrm{P}$.

2.4 DIFFERENTIAL CONTROLLER Hawthorne Ind. Variflo Proportional Control Model H-15l0

2.5 TRANSPORT FLUID Macon Site has silicone oil transport fluid by Dow Corning Q2-1132 in a closed loop flowing between the collectors and the heat exchanger.

Loxahatchee Site has water as the transport fluid in a direct feed system.

2.6 SAFETY FEATURES

Both sites have a Pressure/temperature relief valve at the top of the transport fluid loop and a mixing valve in the hot water to house line. Macon Site has a Diaphram Expansion tank in the fluid transport loop.

Loxahatchee Site has a vacuum breaker at the top of the transport fluid loop and an air bleeder valve at the top 
of the storage tank. These devices were required because of the weekly shut down of the private water system at the Loxahatchee site which drained water from the fluid transport loop and introduced air into the fluid transport loop which eventually found its way to the top of the storage tank causing splattering when the hot water was first turned on.

2.7. FLUID TRANSPORT TUBE 1/2" copper tube insulated with $5 / 8$ Dia. $x 3 / 8$ wall armflex pipe insulation assembled with standard sweat copper fittings and valves. 

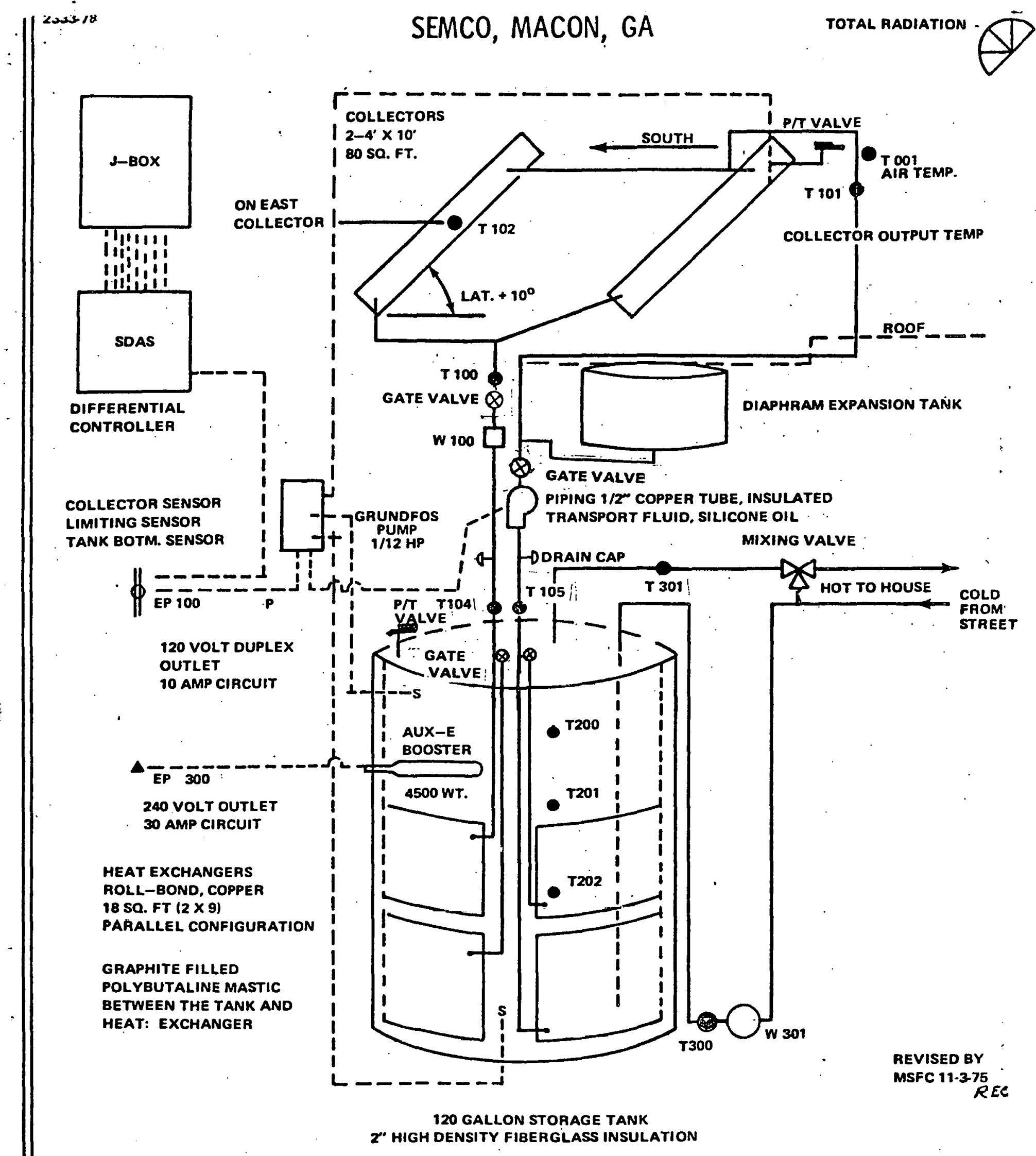

HEAT EXCHANGERS ROLL-BOND, COPPER 18 SO. FT $(2 \times 9)$

PARALlel CONFIGURATION

GRAPHITE FILLED POLYBUTALINE MASTIC BETWEEN THE TANK AND HEAT: EXCHANGER

120 GALLON SOLAR WATER HEATER DOUBLE WALL HEAT EXCHANGER PUBLIC HOUSING PAOJECT

1777 WREN AVE

MACON, GEORGIA

OFF EISENHOWER PARKWAY

PAGE 

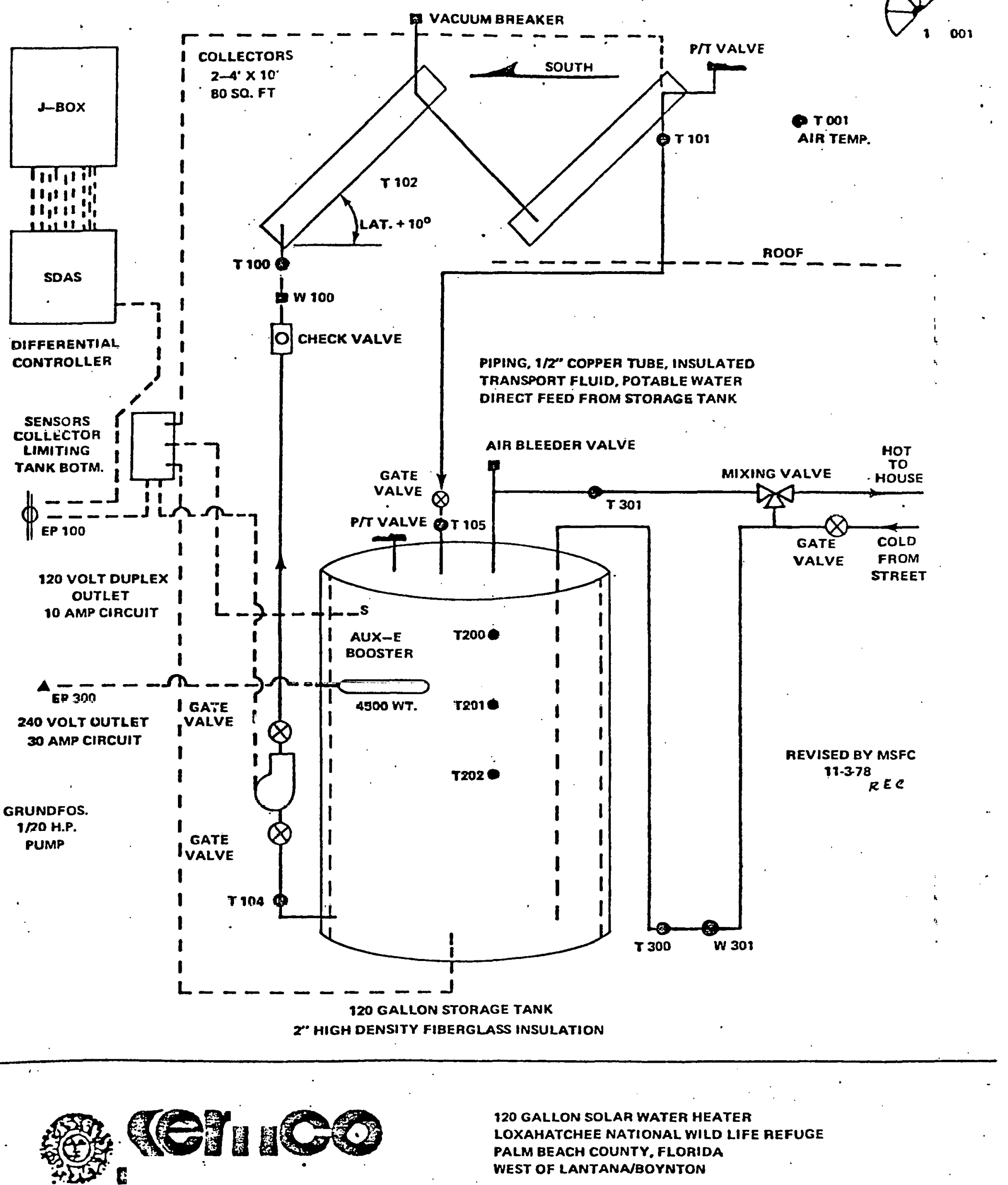

120 GALLON SOLAR WATER HEATER LOXAHATCHEE NATIONAL WILD LIFE REFUGE PALM BEACH COUNTY, FLORIDA WEST OF LANTANAVBOYNTON 
HAZARD ANALYSIS

There are only two major system hazards that require attention. The first is that oi hurricane winds blowing the collectors off the roof ard causing damage to adjacent property. This problem has been overcome by anchoring: each collector to the roof at four separate points and. having the anchoring procedure designed and certified by a Professional Engineer. This has been done for the subject contract. The seconci hazard consideration is that of static loading and pressure build up in the collector. This problem has been overcome by installing a Temperature-pressure relief valve at the upper collector hot water outlet with a blow off line leading down to within 4 to 6 in. of the roof surface. This safety feature has been designed into the system. 
INSTALLATION

TABLE OF CONTENTS

$\begin{array}{lc}\text { Installation, Operation and Maintenance Mannual } & \text { Page } \\ \text { SEMCo Solar Water Heater Installation Procedure } & 17 \\ \text { Collector Installation } & 17 \\ \text { Transport Line Installation. } & 19 \\ \text { Storage Tank Installation } & 20 \\ \text { Solar Schematic } & 21 \\ \text { Controller Installation } & 23 \\ \text { System start-up } & 24 \\ \text { Operating Procedure and Maintenance } & 25 \\ \text { SEMco Guarantee } & 25 \\ \text { SEMCo Collector Drawings } & \end{array}$


The SEMCO solar water heater system is comprised of four subsystems listed as follows:

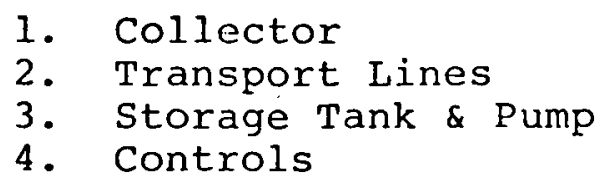

Each subsytem should be installed in the sequence listed above.

\section{COLLECTOR INSTALLATION}

The SEMCO solar collector is a complete factory manufactured item that needs no field work other than the assembly and anchoring of the mounting brackets and the bolting of the collector to the brackets. Each set of mounting brackets is factory cut for the particular roof surface on which the collectors are to be mounted.

The first step is to assemble the mounting brackets into their triangular configuration and attach the mounting feet as pictured below.

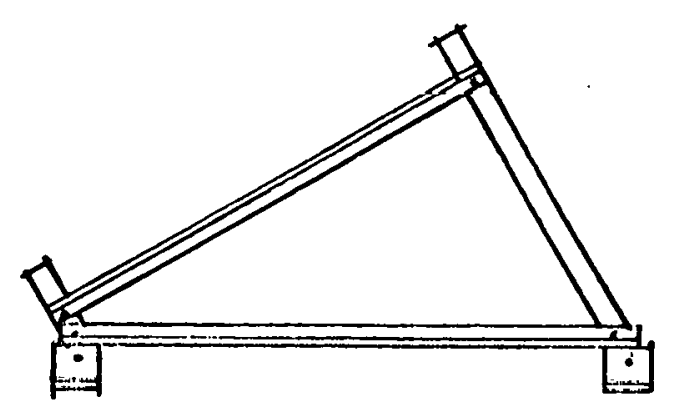

$11 / 2 " \times 1 / 2 "$ Alum. Angle Mounting Bracket

4" $x$ 4" Alum. Angle 4" Long Mounting Feet 
The assembled mounting brackets are next located on the roof surface where the collectors are to be mounted. The two mounting brackets should be spaced 60 to 72 inches apart depending on the rafter system supporting the roof. When the rafter system and spacings are determined, one of the following four bolting systems should be used.

1. Anchoring may be done with $1 / 2$ in. " $J$ " Bolts where an exposed bolt is not objectionable.

2. Where the ceiling under the mounting roof is exposed decorative beam, drill up thru the beam and roof sheating and install $1 / 2$ in. carriage or countersunk $1 / 2$ in. machine bolts.

3. Where the ceiling under the mounting roof is finished plaster, locate the rafters through the roof surface, drill $2-1 / 4$ in. holes 4 in. deep into the rafter and install $2-3 / 8$ in. $x 6$ in. lag bolts for each mounting foot.

4. Where the collectors are mounted on a t.russ or frame roof, install a $1 / 2$ in. bolt through the roof sheating and install a $2 \times 4$ spreader under the rafter system to distribute the lift across two or more rafters or trusses.

After drilling the bolt holes but before bolting the mounting brackets in place, a pitch pan is nailed in place at each mounting foot location. The mounting brackets are then bolted into place and the pitch pans filled with roofing compound.

Finally the collectors are placed in the mounting brackets and lag bolted together through the predrilled holes provided. When the collectors are moved from the ground to the roof location, care must be taken not to rack the collector frame as it may cause the glass to break.

Tools required for this work are as follows:

1. Hammer

2. Screwdriver

3. Set of socket wrenches and/or end wrenches

4. $3 / 8$ inch power drill \& extension cord

5. Set of drills

6. Electric impact wrench (optional) 
The transport 1 ines*are standard soft rolled copper tube with a $3 / 8$ inch O.D. This tube is called $1 / 4$ inch although the I.D. is approximately $5 / 16$ inch. The coil of tube is rolled out and cut to length to run through the attic space from the collectors to the storage tank. Armaflex tube insulation in $6 \mathrm{ft}$. lengths is slipped over the cut to length tube and each joint secured with duct tape. Leave approximately $3 \mathrm{ft}$. of uninsulated tube at each end. Drill three $3 / 8$ inch holes through the roof near the collector input and output tubes. Nail a pitch cup inplace so the three holes are inside the cup. Push the two transport lines through two of the $3 / 8$ inch holes. Hand bend $1 \mathrm{ft}$. length of. $3 / 8$ inch tube into the shape of a fish hook and install in the third hole. This tube is for the controller sensor wires. Fill the pitch pan with roofing compound. Install cut to length armaflex insulating tube over the exposed transport line tubes. Install the prefabricated sensor well and $P / T$ valve assembly in the collector output tube and attach the transport tube in the fitting provided. Attach the second tube to the collector input tube with the $3 / 4$ inch $\times 3 / 8$ inch adapter elbow provided. Insulate all exposed copper tube and secure with duct tape. Drill two $3 / 8$ inch holes in ceiling over the storage tank and push the uninsulated ends of the transport lines through the holes. At this time a $1 / 8$ inch hole can be drilled through the ceiling for the collector sensor wire. "The installation of the collector sensor wires can be done at this time to save a second trip through the attic. Tools required for this work are the same as for the storage tank installation.

* Transport line sizes have been increased to $1 / 2 " I$. D .

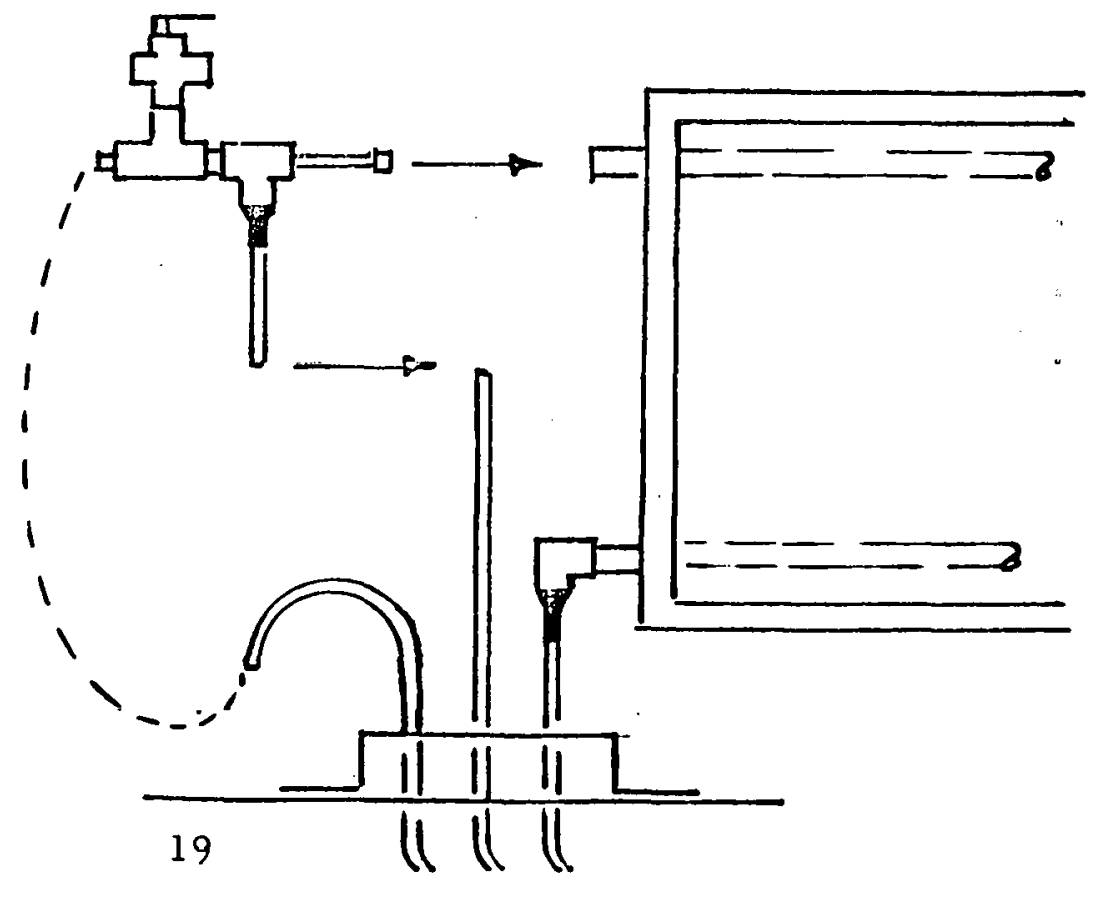


The SEMCo solar storage tank is a complete factory manufactured item that is installed like any standard electric water heater plus the two extra copper transport lines for the solar loop to and from.the roof. Place the storage tank in its permanent location and make the following pipe hookups :

1. Cold from Street

2. Hot to House

3. $\mathrm{P} / \mathrm{T}$ Valve

4. Collector input line to tank bottom solar fitting.This line includes the circulating pump and check valve

5. Collector output line to tank top solar fitting. This line includee the thermometer.

See the following solar schematic for a visual description of this work.

The 220 Volt/30 Amp electrical hookup for the booster heater element should be made at this time but left disconnected. This electrical work should be done in accordance with local standard practice and/or local code.

Tools required for this work are as follows:

1. Pipe Cutter

2. Soldering Torch

3. Sandpaper, Solder Flux \& Solder 


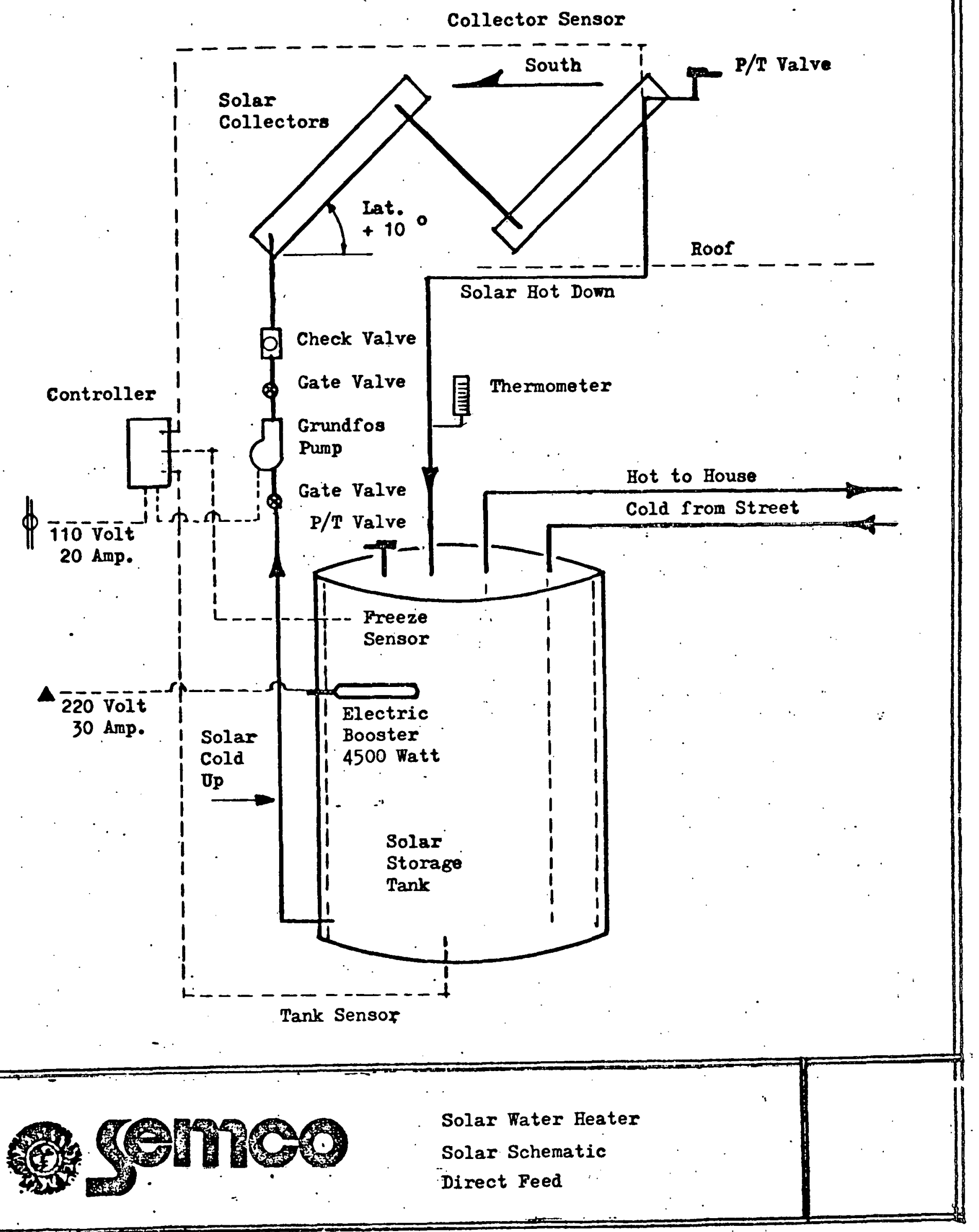




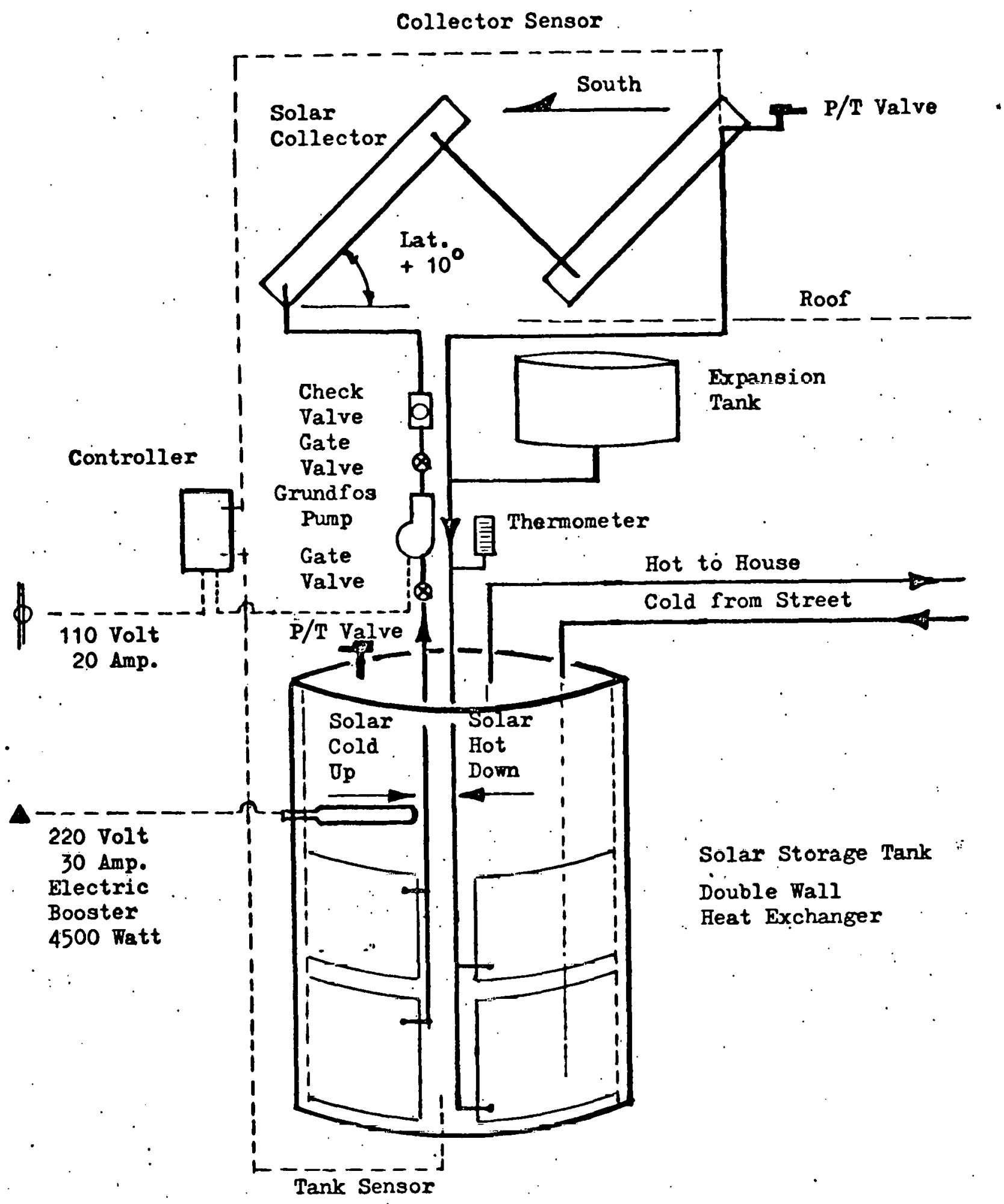

Solar Water Heater

Solar Schematic

Double Wall Heat Exchanger 


\section{CONTROLLER INSTALLATION}

The SEMCo controller is an electronic device that senses the difference in temperature between the collector output temperature and the tank bottom temperature. When the collector temperature is greater than the tank bottom temperature, the controller turns the circulating pump on. The collector sensor has been factory installed in the sensor well and is in place when the sensor well has been installed as described in the installation of the transport lines. The tank sensor has also been factory installed. To install the controller system, place the controller box on the top surface of the storage tank and connect the two pairs of wires from the collector and tank bottom to the terminals marked "coll." and "tank" on the back of the controller box. For geographic locations where direct feed is possible, a freeze sensor is provided in the sensor well. This pair of wires should be connected to the terminal marked "Frez".

The electric cord from the circulating pump is plugged into the outlet provided on the back of the collector box and the collector box is plugged into a 110 Volt/10 Amp electrical outlet. If all the connections have been made correctly, the circulating pump will start. Quickly unplug it because the pump can be damaged if allowed to run dry for any length of time. 
SYSTEM START-UP

Having completed the installation of the four subsystems the complete system is now ready for start up. For the direct feed system, first, open the cold water cut-off valve and fill the storage tank with water and check for leaks. Next, open the P/T Valve on top of the collector and bleed off a 11 air and again check for.leaks.

The system is now ready to start up. Plug the controller into the 120 Volt outlet. The circulating pump will move cold water from the bottom of the tank into the solar collectors where it will be heated. The hot water will flow down into the top of the storage tank. The thermometer will register the temperature of the collector output water.

For the double wall heat exchanger solar tanks, the start-up procedure is to first fill the storage tank with water and check for leaks. Next, fill the solar circulating loop with the anti-freeze liquid provided by removing the $P / T$ Valve on top of the collector and pouring the liquid into the system. All air should be bled from the solar loop and the $P / T$ Valve replaced. The startup procedure is the same as described above for the direct feed system.

Finally, plug the electric booster into the 220 volt outlet. 
After completing the start-up procedure, the system will operate automatically for years with no adjustments or maintenance required.

The only possible malfunction that could cause the system not to operate correctly, would be air trapped in the cir-. culating loop of the double wall heat exchanger system. If the thermometer shows no hot water flowing from the collector to the storage tank, remove the collector $\mathrm{P} / \mathrm{T}$ Valve again and add more anti-freeze liquid to replace the entrapped air.

\section{SEMCO GUAR ANTEE}

The SEMCO Solar water Heater is guaranteed for five (5) years against defects in material and workmanship under normal operating conditions. Should the controlier or pump malfunction within five (5) years of the date of installation; return the defective part to the SEMCO plant for repair or replacement. 


\section{FLAT PLATE SOLAR COLLECTOR}

The Semco flat plate solar collector is designed to absorb and trap direct and diffused solar radiation. The absorbed energy is transferred by conduction and convection to the collector tubing which heats water circulating through the collector. This heated water can be used to supply residential and commercial needs for hot water. The collectors can also be used to heat swimming pool water and supply the hot water requirements for space heating and cooling.

The collector plate is constructed of $3 / 4$ inch copper tubing on 6 inch centers soldered to a grooved copper plate. The surface facing the sun is painted with a flat black industrial enamel.

The collector box is constructed of aluminum and insulated with polyurethane. The glazing is standard double strenyth window glass * with aluminum mullions and frame.

\section{SOLAR WATER HEATER}
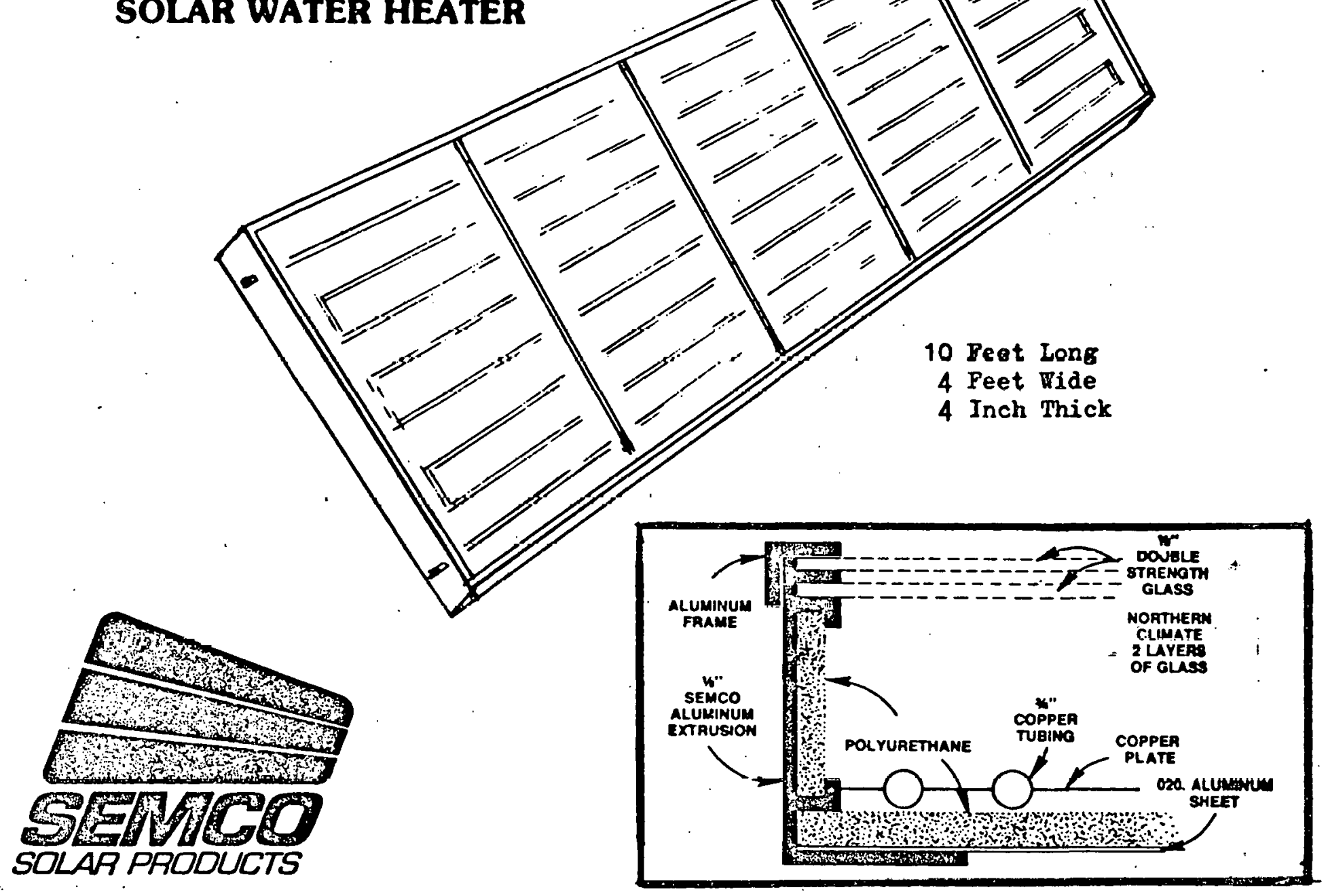

plate glass changed to tempered glass 
Liquid Flat Flate Solar Collector

Section -- Full size

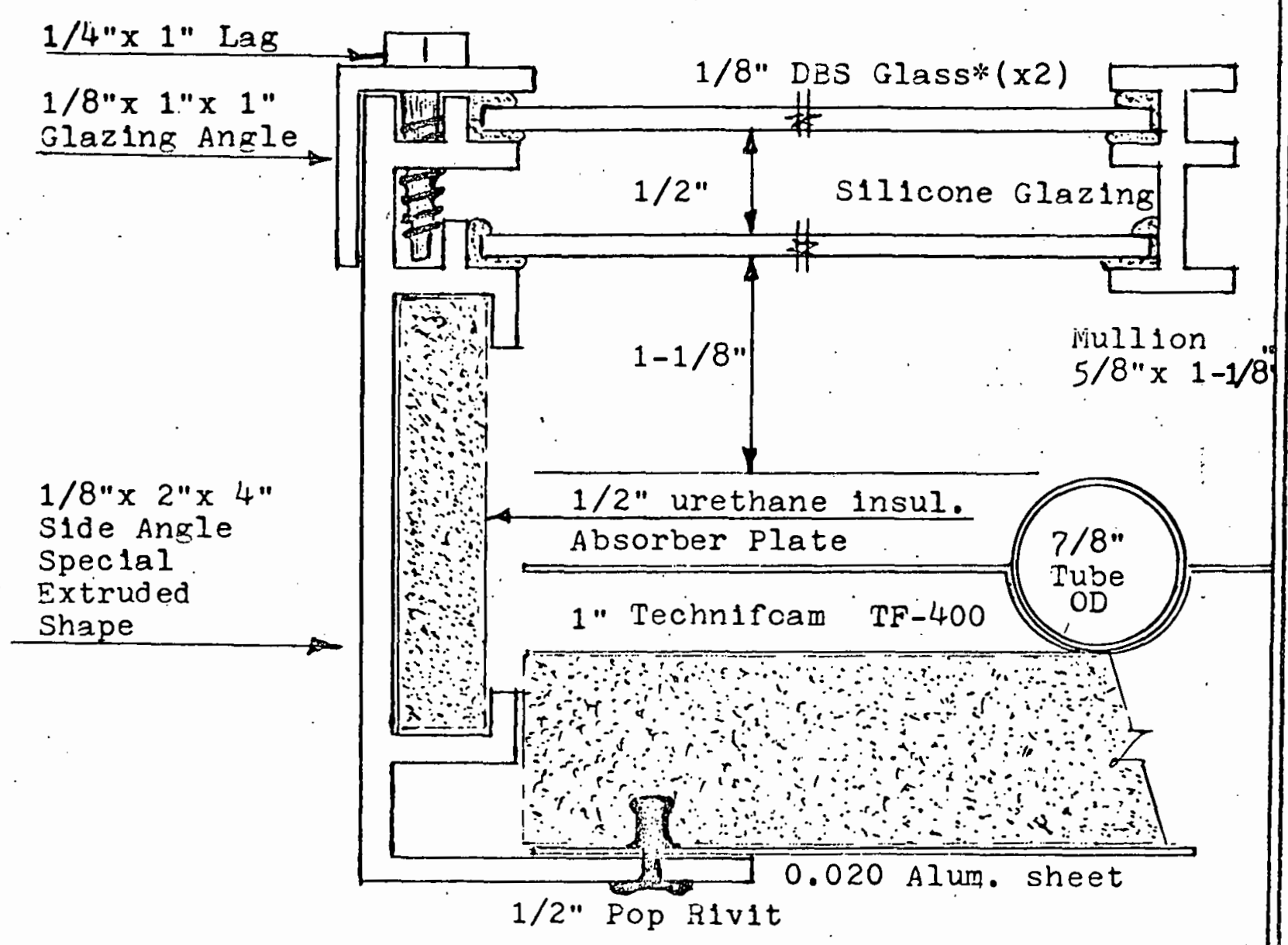

* plate glass changed to tempered glass

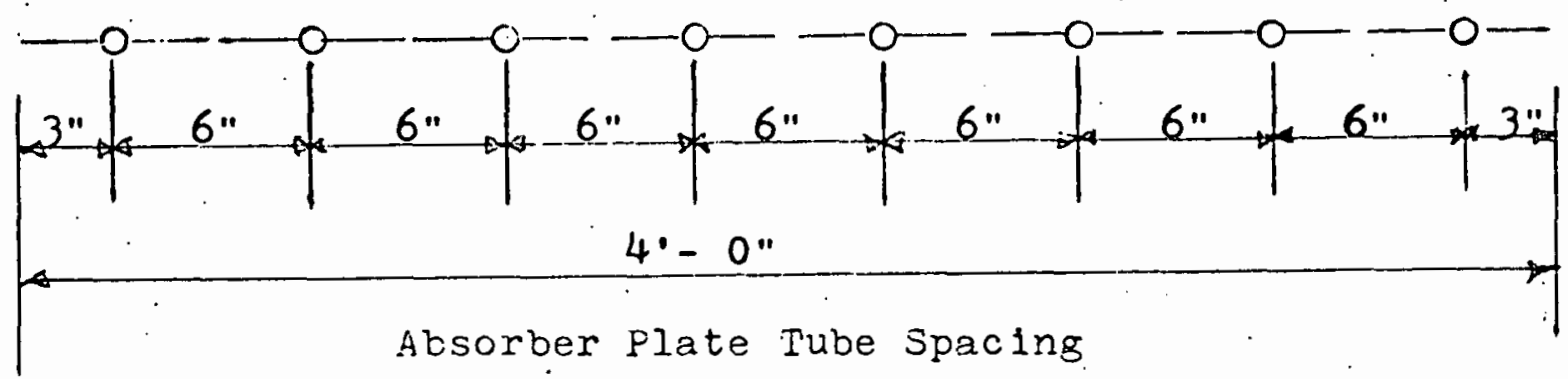

Solar Engineering \& Manufacturing Company, Inc 
Liquid Flat Plate Solar Collector Box Deta1ls - $1 / 2^{\prime \prime}=1^{\prime}-0^{\prime \prime}$
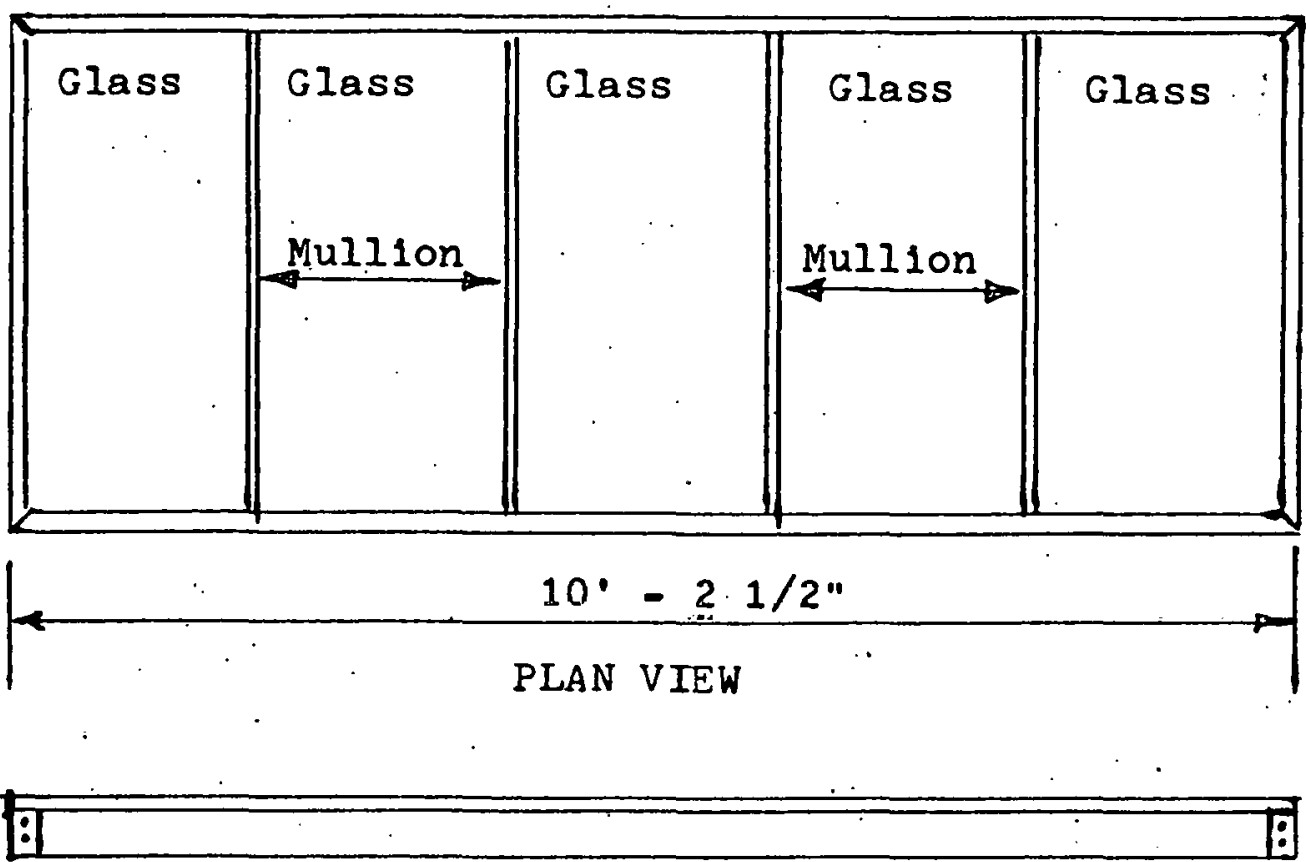

SIDE VIEW

Glazing Angle

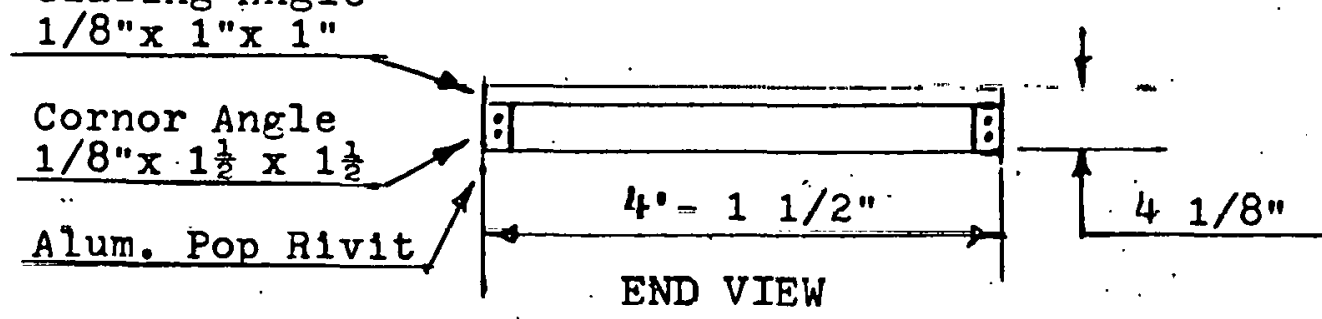

Material - Aluminum - "606-T6

Aluminum Box - 1/8"x 2"x 4" side angle - 0.020 Alum. Bottom "Glazing - Double - 1/8" DBS Glass - 5 pcs. 24" x 48" Inoulation = 1" Technifoam - TF-400 - $\mathrm{R}=9$ Absorber Plate - $3 / 4$ Copper Tube finned with 0.010 sheet Copper Absorber Surface - Non-selective flat black enamel Tube Configuration - Serpentine

* plate glasss changed to tempéred glass

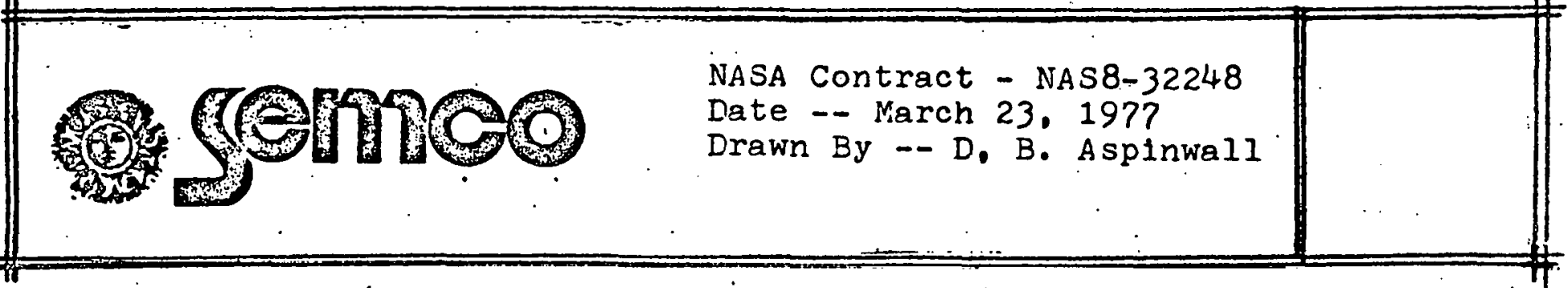

Solar Engineering \& Manufacturing Company, Inc. 
A. Terminal Box

B. Switch

C. O-rings

D. Rotor Can

E. Top Bearing

F. Stator

G. Gasket

H. Bearing Plate

I. Flow Adjustment Arm

J. Variable Flow Adjustment Plate

K. Impeller

L. Bottom Bearing

M. Thrust Bearing

N. Pump Chamber

O. Stator Housing

P. Rotor

Q. Winding Protection

R. Shaft .

S. Plug/Indicator

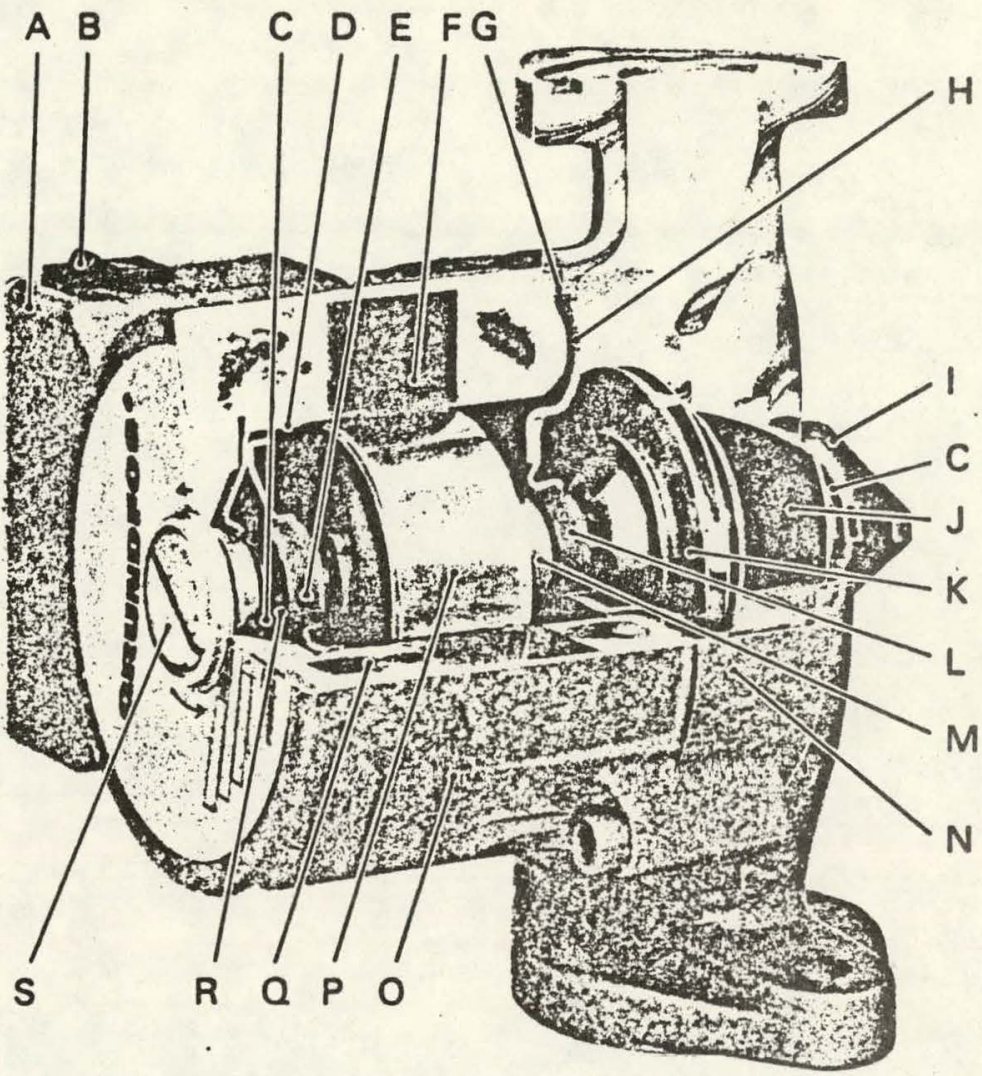

INFORMATION: Two-speed circulator pump - UPS 20-42

The UPS $20-42$ is fitted with a variable flow control and also features a two-speed motor. The head is controlled by the flow adjustment arm (I) and the choice of speed is made by hand on the switch (B) or made automatically in conjunction with remote control.

\section{CONSTRUCTION}

The UPS 20-42 is a water lubricated pump. However, in order to protect the rotor $(P)$ and bearings $(E, L)$ from damaging impurities which may be present in the circulating water, they are separated from the stator $(F)$ and the pump chamber by a liquid filled rotor can (D). The motor shaft (R) extends out from the rotor can, into the pump chamber through the aluminum oxide bearing (L), which also functions as a seal. During initial operation, the pump is automatically self-vented; however, due to the isostatic principle, there is no further recirculation of water into the closed rotor can. The pump's "diamond-hard" aluminum oxide bearing construction, combined with the high starting torque of the motor, ensures re-start after shutdown.

\section{MATERIALS}

Stainless steel:. . ........... Rotor can, shaft, rotor. cladding, bearing plate, impeller, variable flow adjustment plate, thrust bearing cover.

Aluminum oxide:............ Top bearing, shaft ends, bottom bearing.

Aluminum:................ Stator housing.

Carbon/aluminum oxide: ......... Thrust bearing.

Cast iron: ................... Pump housing.

Ethylene/propylene rubber:....... O-rings, gasket.

Silicone rubber: .............. Winding Protection.

\section{APPLICATIONS}

The UPS 20-42 should only be used in closed systems (i.e. solar, hydronic) for the circulation of water. However, solutions such as ethylene glycol can be used without hindering pump performance. For open systems, order the Grundfos model UP 25-42 SF which has an all stainless steel pump housing. 